\title{
Geotechnical in situ characterization of subaquatic slopes: The role of pore pressure transients versus frictional strength in landslide initiation
}

\author{
Sylvia Stegmann, ${ }^{1}$ Michael Strasser, ${ }^{2}$ Flavio Anselmetti, ${ }^{2}$ and Achim $\mathrm{Kopf}^{1}$ \\ Received 26 December 2006; revised 26 February 2007; accepted 7 March 2007; published 11 April 2007.
}

[1] Mineralogical composition and pore fluid pressure are the crucial controls for mechanical stability of watersaturated sediments. Their in situ measurements were undertaken in earthquake-triggered slope deposits in Lake Lucerne (Switzerland) in addition to geophysical characterization and laboratory index properties, shear and consolidation experiments on core. Two lithological units were identified: A weak, lightly underconsolidated section of postglacial silty clays overlies overconsolidated finegrained glacial deposits with coarser components and excess fluid pressure (ca. $2.5 \times$ higher than in the hanging wall clay). In the event of an earthquake, hydrofracturing in the overconsolidated section facilitates an upward pore pressure pulse to the base of the softer, less stable unit. Here, excess pore pressure initiates sliding along a failure plane at the lithological boundary, causing the entire postglacial sedimentary section to slip downslope. We propose that many submarine landslides at active and passive continental margins may follow this mechanism of pore pressure-induced failure. Citation: Stegmann, S., M. Strasser, F. Anselmetti, and A. Kopf (2007), Geotechnical in situ characterization of subaquatic slopes: The role of pore pressure transients versus frictional strength in landslide initiation, Geophys. Res. Lett., 34, L07607, doi:10.1029/2006GL029122.

\section{Introduction}

[2] Measurement of pore fluid pressure as a crucial factor controlling effective strength and mechanical behavior of saturated sediments is a difficult task, because the measurement itself disturbs the hydrologic regime [Schultheiss, 1990; Lee and Elsworth, 2004]. Otherwise, pore pressure is a fundamental parameter for the understanding of the stability of (saturated) sediments and hazards. The stability of sediment is controlled by shear strength $\tau$ at a given normal stress $\sigma_{\mathrm{n}}$, where friction coefficient $\mu$ is the ratio between the two and pore pressure $\mathrm{P}$ lowers effective normal stress $\left(\tau=\left[\sigma_{\mathrm{n}}-\mathrm{P}\right] \mu\right)$ [Hubbert and Rubey, 1959]. Extensive research concerning the stability of marine sediments has been carried out [e.g., Biscontin et al., 2004; Sultan et al., 2004]. Much of the geotechnical data on landslide sediments were derived in laboratory experiments [e.g., Ilstad et al., 2004], and rather little is known about in situ sediment strength and pore pressure [Baltzer et al.,

\footnotetext{
${ }^{1}$ Research Centre Ocean Margin, University of Bremen, Bremen, Germany.

${ }^{2}$ Geological Institute, Eidgenössische Technische Hochschule, Zurich, Switzerland.
}

Copyright 2007 by the American Geophysical Union. 0094-8276/07/2006GL029122
1994]. Despite the difficulty of in situ pore pressure measurements in marine sediments, however, seagoing piezoprobes measuring pore pressure [e.g., Davis et al., 1991] and additionally sediment strength [Stegmann et al., 2006] have been developed recently. This paper presents results from the study of earthquake-induced subaquatic slope failure in Lake Lucerne (Switzerland) using in situ vane shear and Cone Penetrating Testing (CPT) devices to obtain the key geotechnical parameters. These data help distinguish between the role of pore pressure vs. mineralogically controlled strength and their ramifications for landslide initiation. Furthermore the in situ data complement an extensive geophysical and sedimentary data base [Strasser et al., 2007] and are used for comparison with laboratory-derived pre-consolidation stresses. With the unique, comprehensive set of largely in situ data, we are able to unambiguously distinguish the relative role of fluids vs. sedimentary constituents in failure of slope sediments.

\section{Geological Setting}

[3] This study focuses on the biggest subaqueous mass movement (Weggis Slide) of perialpine, glaciallyoverdeepened Lake Lucerne, central Switzerland (Figure 1). A detailed description of the slope and sediment characteristics is given by Schnellmann et al. [2005] and Strasser et al. [2007]. In summary, the translational tsunamigenic landslide mobilized $\sim 8.5 \times 10^{6} \mathrm{~m}^{3}$ of sediment and was triggered by a $M \sim 6.2$ earthquake that hit the Lucerne area in 1601 A.D. The intact sedimentary succession covering the $\sim 10-15^{\circ}$ dipping glacially eroded bedrock adjacent to the prominent 1601 A.D.-failure scar consists at the base of thin (1-3 m thick) glacially deformed, glacio-lacustrine sediments (in this paper assigned to glacial deposits, unit 2), that are overlain by 4-6 m of Late Pleistocene to Holocene fine-grained lacustrine drape deposits (here assigned to postglacial deposits, unit 1). The failure surface of the Weggis Slide, as revealed by high-resolution $3.5 \mathrm{kHz}$ acoustic seismic profiles (Figure 1) and sediment cores coincides with the lithological boundary between the glacial and postglacial deposits.

\section{Methods}

[4] From a moored platform, an in situ vane shear probe (Genor A/S) and a free-fall cone penetrometer [Stegmann et al., 2006] were deployed. Both devices sank by their own weight into the soft, clay-rich sediment adjacent to the failure scar (Figure 1). Local water depth was $31.5 \mathrm{~m}$ (hydrostatic pressure $\left[\mathrm{P}_{\text {hyd }}\right] \sim 309 \mathrm{kPa}$ ). In situ vane shear tests were performed at $30-$ and $50-\mathrm{cm}$ intervals using a 


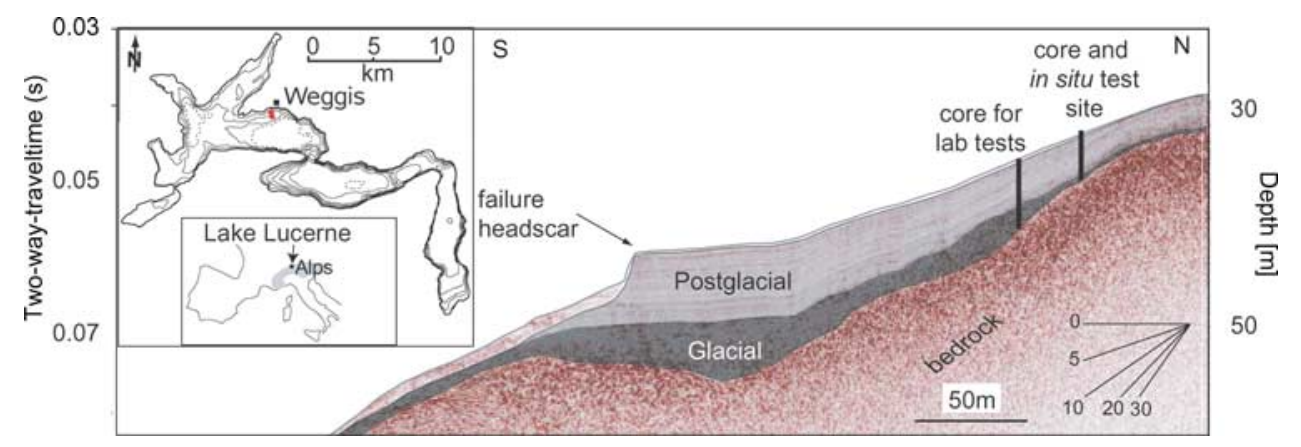

Figure 1. $3.5 \mathrm{kHz}$ seismic reflection profile across the Weggis Slide showing the morphology of the slide and the different lithological units. The black bar marks the location of coring and in situ testing.

$6.5 \mathrm{~cm}$ diameter vane. Penetration depth of the probe was taken from the wire length. At each target depth the probe was extruded carefully from the casing into the undisturbed sediment and rotated mechanically from the platform at a constant rate of $6 \%$ min until failure occurred. A $15 \mathrm{~cm}^{2} \mathrm{CPT}$ probe mounted to a lance-shaped autonomous instrument was deployed in the same stepwise-fashion. During insertion of the penetrometer, cone resistance $\mathrm{q}_{\mathrm{c}}$, sleeve friction $f_{s}$ and pore pressure $u_{2}$ were measured to determine the stiffness and the excess pore pressure of the sediment. The lance was held at each penetration level for 10 minutes to observe the dissipation of the induced pore pressure signal towards ambient in situ values. Additionally, CPT data were used to estimate undrained shear strength $\mathrm{S}_{\mathrm{u}}$. Depending on the mode of failure, soil anisotropy, strain rate, and stress history, a theoretical relationship between $\mathrm{S}_{\mathrm{u}}$ and corrected cone resistance $\mathrm{q}_{\mathrm{t}}$ can be used (see summary by Lunne et al. [1997]): $\mathrm{S}_{\mathrm{u}}=\left(\mathrm{q}_{\mathrm{t}}-\sigma_{v \mathrm{o}}\right) / \mathrm{N}_{\mathrm{k}}$, where $\mathrm{N}_{\mathrm{k}}$ is an empirical cone factor and $\sigma_{v \mathrm{o}}$ is the in situ total vertical stress. $\mathrm{N}_{\mathrm{k}}$ averages 15 for normally consolidated clays and 17 for overconsolidated clay [Lunne et al., 1997]. Assuming that the insertion pore pressure is dominated by a pressure pulse associated with the displacement and/or compaction of the sediment, Esrig et al. [1977] suggest an empirical relationship for soft saturated sediments between the maximum pore pressure during insertion $\mathrm{U}_{\text {imax }}$ and $\mathrm{S}_{\mathrm{u}}: \mathrm{S}_{\mathrm{u}}=\mathrm{U}_{\text {imax }} / 6$. Regarding the relationship between $S_{u}$ and $U_{\text {imax }}$, we use the maximum pore pressure within the 10 minutes window ignoring the artificial excursion of the pressure signal during impact. This procedure is based on the assumption that at the end of each testing period, pore pressure values are closest to ambient background values. Laboratory measurements were carried out on two sediment cores adjacent to the site where the in situ tests were performed (Figure 1). Sediment bulk density was measured using a multi-sensor core logger (GEOTEK) at ETH Zurich. Grain size analyses were performed using laser diffraction techniques at $\sim 10-\mathrm{cm}$ intervals along the split core. Clasts $>2 \mathrm{~mm}$ in the glacial sediments were extracted and measured prior to analysis. Every $15 \mathrm{~cm} \mathrm{~S}_{\mathrm{u}}$ was measured on the same split core using a standard laboratory vane shear device. In addition, ring shear and oedometer tests were carried out on the two distinct lithologies, i.e. above $(3.5 \mathrm{~m}$ core depth) and beneath $(6.3 \mathrm{~m}$ core depth) the sliding surface. Ring shear tests were conducted using a custom-built Bromhead ringshear apparatus at RCOM Bremen. Progressive loading increments up to normal stresses of between 100 and $400 \mathrm{kPa}$ were performed corresponding to the in situ normal stress of the tested specimens. After consolidation, the samples were sheared under drained conditions at a rate of $0.001 \mathrm{~mm} / \mathrm{s}$ until peak strength was reached. On the residual path of each experiment, rate-dependency and frictional behavior of drained shear strength were tested at different rates $(0.0005,0.01$ and $0.1 \mathrm{~mm} / \mathrm{s})$. The uniaxial compression behavior of the sediments was studied using an oedometer after Terzaghi [1925] with progressive loading increments from $5 \mathrm{kPa}$ to $4 \mathrm{MPa}$ effective stress. Experiments on the glacial and postglacial sediments served to evaluate the consolidation behavior, expressed by the overconsolidation ratio $\mathrm{OCR}=\sigma_{\mathrm{c}}^{\prime} / \sigma_{\mathrm{o}}^{\prime}$, with $\sigma_{\mathrm{c}}^{\prime}$ known as the preconsolidation stress sensu [Casagrande, 1936] and $\sigma_{\mathrm{o}}^{\prime}$ as the overburden stress.

\section{Results}

[5] The combination of in situ and laboratory measurements provide a consistent characterization of the sediment properties immediately upslope of the Weggis Slide scar, and allow us to define two lithological units on the basis of geotechnical data (glacial vs. postglacial). Both types of sediments are dominated by silt and clay $(40 \%$ and $55 \%$, respectively) with max. $20 \%$ sand in the glacial unit (Figure 2a). In the postglacial section, CPT data show a continuous increase of $\mathrm{q}_{\mathrm{c}}$ with depth reaching $150 \mathrm{kPa}$, whereas $\mathrm{f}_{\mathrm{s}}$ vary between 0.5 and $2 \mathrm{kPa}$ (Figure $2 \mathrm{~b}$ ). Below $3.8 \mathrm{~m}$ both parameters rise abruptly to 318 and $5.2 \mathrm{kPa}$, respectively, before $\mathrm{q}_{\mathrm{c}}$ decreases within the glacial unit to a value of $240 \mathrm{kPa}$ at the bottom of the depth profile (Figure 2b). Pore pressure follows the same trend as $q_{c}$ and $f_{s}$, with higher excess pore pressures in the lower (glacial) unit (Figure 2c). In a typical measurement, a spike in pore pressure in unit 1 is induced upon insertion, followed by a non-linear asymptotic decrease towards background values. Here, pore pressure dissipates to about $70-80 \%$ of the insertion value after 10 minutes. In contrast, the underlying glacial unit shows negative pressures upon insertion, which are then followed by an increase in pore pressure during the 10 minutes recording. We interpret this increase to indicate ambient overpressures, which is supported by high values up to $80 \mathrm{kPa}$ above $\mathrm{P}_{\text {hyd }}$ after 10 minutes. When undrained shear strength based on CPT data is compared to in situ and laboratory vane shear tests, a similar trend is recognized (Figure 3). Depending on the method, $\mathrm{S}_{\mathrm{u}}$ in postglacial deposits ranges between $0.5-$ $4.5 \mathrm{kPa}$ (Figure 3a), 3-6.5 $\mathrm{kPa}$ (Figure 3b), and $1.5-6.5 \mathrm{kPa}$ (Figure 3c). In the glacial unit, $\mathrm{S}_{\mathrm{u}}$ increases up to $16 \mathrm{kPa}$ 
a)

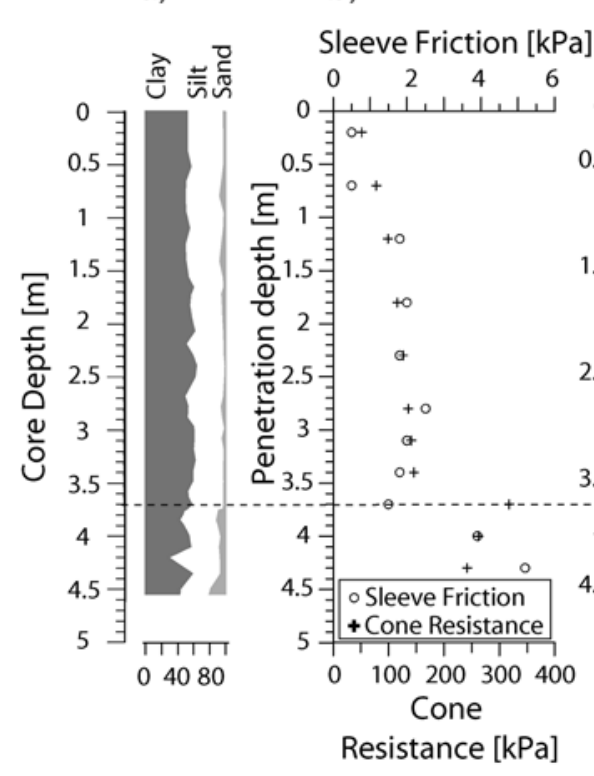

c)

)

7

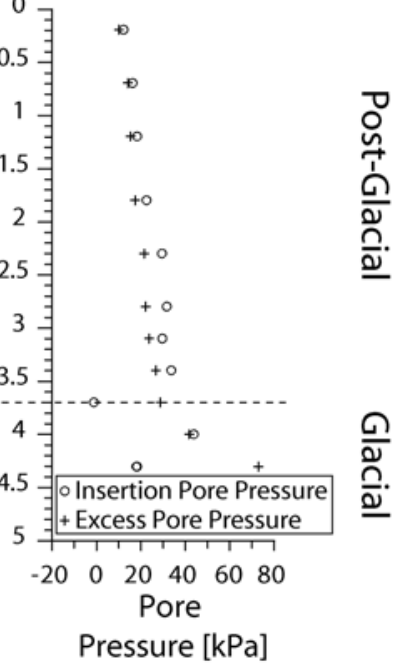

Figure 2. Physical and sedimentary properties along the Weggis slope, measured on a core and in situ. (a) Grain size distribution, (b) in situ CPT cone resistance and sleeve friction, and (c) in situ pore pressure measured during CPT insertion and after 10 minutes.

(Figures $3 b$ and $3 c$ ). in situ $S_{u}$ derived from $q_{c}$, agrees well with the lab vane shear (Figures $3 b$ and $3 c$ ), whereas in situ measurements using the vane shear probe are significantly lower $(<8 \mathrm{kPa}$ in the glacial clay; Figure $3 \mathrm{a})$. The discrepancy between in situ vane shear and CPT data may be partly explained by a general underestimation of the first caused by the pre-disturbance of the sediment by the insertion of the device before shearing and, moreover, by uncertainties when choosing the empirical factor $\mathrm{N}_{\mathrm{k}}$ for calculating $\mathrm{S}_{\mathrm{u}}$ from CPT data [Karakouzian et al., 2003]. However, an overall increase in strength in the lower unit can be observed regardless of the method. Ring shear tests serve to measure the mineralogically controlled frictional behavior at quasi-infinite strain. Our results show a similar mechanical behavior for glacial and postglacial sediments.

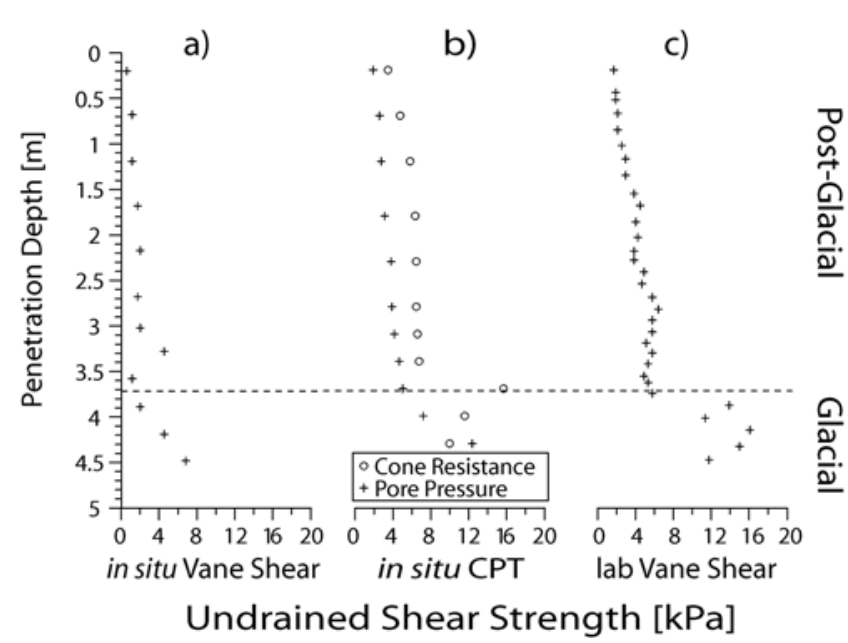

Figure 3. Undrained shear strength based on (a) in situ vane shear probe, (b) in situ CPT, and (c) laboratory vane shear probe.
Peak shear strength ranges between 41 and $143 \mathrm{kPa}$ at 100 and $400 \mathrm{kPa}$ normal stress, leading to friction coefficients of approximately $0.36-0.4$ for either lithology, which is typical for silty clay [Lupini et al., 1981; Logan and Rauenzahn, 1987; Brown et al., 2003]. Also, both the glacial and postglacial sediments show velocity strengthening behavior when tested at various shear rates. The overall similarity of the ring shear tests suggests that both sediment types are dominated by clay minerals resulting in similar mechanical behavior (Figure 2a). Oedometer tests on samples from above and beneath the sliding surface reveal that the postglacial sediment is very compressible, slightly underconsolidated $(\mathrm{OCR}=0.86)$, and has a pre-consolidation stress of $19 \mathrm{kPa}$ (see Figure S1 of the auxiliary material). ${ }^{1}$ Glacial sediments, however, are characterized by a lower compressibility with high pre-consolidation stresses of 100 $\mathrm{kPa}^{\mathrm{a}}$ and overconsolidation $(\mathrm{OCR}=1.58)$, the latter resulting from glacial compaction [see Strasser et al., 2007].

\section{Discussion}

[6] It has long been known that fault initiation, propagation and slip are a function of fault zone mineralogy and transient pore pressure [Hubbert and Rubey, 1959]. Separating the effect of intrinsic sediment friction from that of pore pressure is one of the major targets in marine soil mechanics. Attempts to achieve this goal usually rely on modelling or estimating the excess pore pressure from geophysical data or water release due to mineral dehydration and gas hydrate processes [Moore and Shipboard Party ODP Leg 156, 1995; Brown et al., 2001; Saffer et al., 2000]. However, these studies do not include the in situ measurement of pore pressure and are hence hampered by uncertainties. In our study of Lake Lucerne slope deposits, we are

Auxiliary materials are available in the HTML. doi:10.1029/ 2006GL029122. 


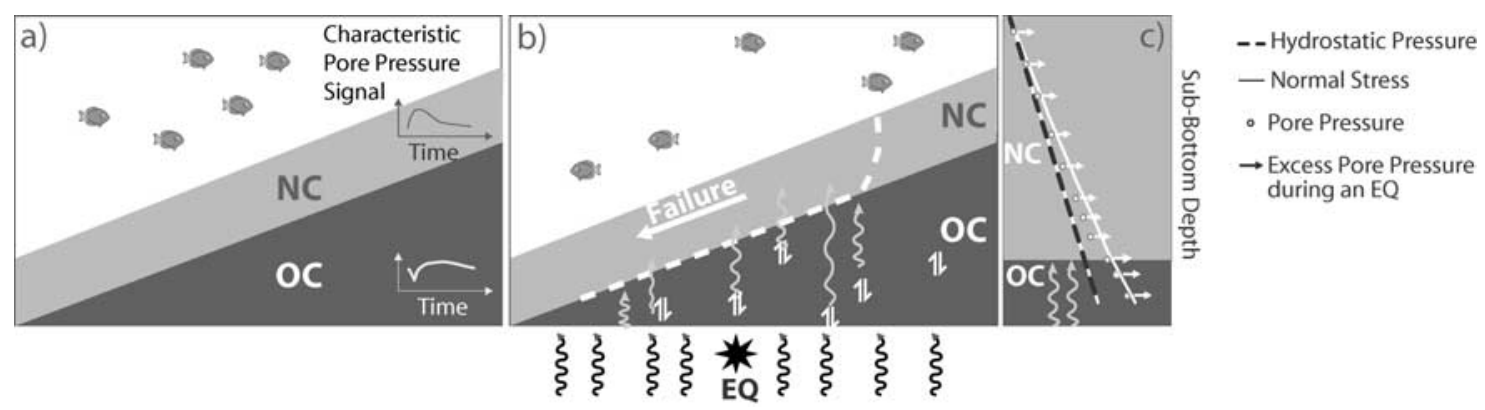

Figure 4. Conceptual model of the forces acting on and within a sedimentary sequence prior and during an earthquake event. Next to the two lithological units, we show diagrams of the typical pore pressure response during CPT tests in those sediments. (a) Pre-failure condition. (b) Failure triggered by an EQ. Wiggly arrows illustrate stress changes from depth and associated pore pressure pulses in the overburden (white wiggly arrows); up-and-down arrows represent hydrofractures. (c) Schematic sketch of effective stress conditions during an EQ, based on actual data (core and CPT). White arrows represent pore pressure increase during an EQ (see discussion).

able to separate the two factors by a suite of in situ and laboratory measurements. On a regional level, our results show a reliable quantitative geotechnical characterization of the undisturbed glacial-to-postglacial succession in the source area of the Weggis Slide, which failed along a planar sliding surface that developed at the lithological boundary between slightly underconsolidated postglacial deposits and overconsolidated glacial deposits. Measured in situ pore pressure can be related to the different states of consolidation (see Figures 1, 2c, and S1), where negative insertion pore pressure in the overconsolidated unit may be generated by dilatant shear behavior with a displacement of fluids during insertion and a following slow increase of pore pressure controlled by the low permeability. We can exclude, that measured negative response is due to suction by pulling back the tool, because the acceleration sensor did not show any movement after insertion. Undrained shear strength, measured and derived with several methods, accentuates the difference in strength and consolidation state between the two lithologies. In contrast, laboratory ring shear frictional properties reveal no significant difference in the mechanical behavior of glacial and postglacial sediments. We conclude that pore pressure (and related lowering of effective stress) rather than the presence of weak mineral phases plays the key role in failure initiation along the Weggis slope. On a broader scale, our results may have important repercussions for triggering of failure processes along marine slopes and continental margins at lowered effective stresses. We condense our result to a model of earthquake-triggered failure initiation along the lithological boundary between two sediment layers with similar intrinsic mechanical behavior, but different consolidation and pore pressure regimes. The underlying overconsolidated sediments have lower permeability and higher shear strength, while their overburden drape is characterized by slightly more permeable, less competent sediments (Figure 4). At constant stress, such a slope is stable (Figure 4a). In case of an earthquake, however, seismic pulses from the poroelastic response to the earthquakeinduced strain generate hydrological transients and - possibly - hydrofractures [Cocco and Rice, 2002]. A stress pulse may disrupt the overconsolidated glacial clay, thereby transferring excess pore fluid pressures up to less stable Holocene deposits (Figure $4 \mathrm{~b}$ ). This model may be transferred from the micro-scale lacustrine realm to the macro-scale landslide prone active and passive margins. Long-term records of pore pressure along the Nankai Trough [Davis et al., 2006] and Costa Rica subduction zones [Brown et al., 2005] and of water-level oscillations on-shore Oregon [Brodsky et al., 2003] have documented the interaction between seismicity and pore pressure as well as its transfusion over tens of kilometres. At the frontal thrust of the Nankai accretionary prism, Davis et al. [2006] have measured up to $>100 \mathrm{kPa}$ increase in pore pressure to low-frequency EQs (M3.5-4.4) some $10 \mathrm{~s}$ of km away. Given that the 1601 A.D. M 6.2 EQ epicenter is only $15 \mathrm{~km}$ from the Weggis site, even a smaller pore pressure pulse may likely have caused values in excess of lithostatic (see arrows in Figure 4c). Hydrofracturing may have been facilitated by the historically documented $4 \mathrm{~m}$-high tsunami waves after the $1601 \mathrm{EQ}$, which caused cyclic normal stress drops and eventually failure. This mechanism seems similar to large-scale landslides in seismic and/or tectonically active regions, where transient pore pressure pulses as main triggers have been proposed. One of the largest landslides is the Storegga Slide on the MidNorwegian shelf $\left(3000 \mathrm{~km}^{3}\right)$. Considering the pre-failure condition for slope instability (rapid loading of clayey sediments, over-pressuring during glaciation cycles and possible dissociation of gas hydrates) initial failure has been linked to a $\mathrm{M}>\sim 7 \mathrm{EQ}$ [Bryn et al., 2005]. Other large mass movements at passive margins are often related to rapid sediment accumulation and overpressures (New Jersey margin; Dugan and Flemings [2000]). Slope failure along convergent margins may be associated with tectonic steepening and fluid venting during subduction processes (e.g., slumps and landslides along the Middle American Trench; von Huene et al. [2004]). At volcanic margins or islands, both seismicity in the magma chamber and hydrothermal circulation adjacent to it influence the pore pressure regime, making these factors responsible for mega-landslides such as those in La Palma, Canary Island (ca. $5000 \mathrm{~km}^{2}$; Masson et al. [2002]) or the Nuuanu Landslide, Hawaiian Islands (ca. $5000 \mathrm{~km}^{2}$; Moore et al. [1994]).

\section{Conclusions}

[7] As a general conclusion, we emphasize that despite variability in regional geological processes and regardless of 
the scale of the mass wasting event, slope instability is often triggered by variations in pore pressure resulting from underlying processes such as sedimentary, glacial, tidal, storm-wave and tectonic loading, gas hydrate processes, or EQ tremor [Hampton et al., 1996; Locat, 2001]. The reliable in situ measurement of pore pressure, ideally over longer periods of time, will be the most promising step towards a more complete understanding of landslide initiation, risk assessment and mitigation.

[8] Acknowledgments. We thank Robert Hofmann, Felix Bussmann and Benjamin Dürr from ETH Zürich for their help and enthusiasm during the measurements on Ararat platform in fall 2005. We thank the Limnologic Research Center of Eawag for providing logistic support during the field campagn. Beat Rick is acknowledged for assisting with the in situ vane shear device (Dr. von Moos AG, Zürich). Tobias Mörz and Stefan Kreiter are acknowledged for discussion and help with oedometer testing at RCOM Bremen. We thank Peter Clift for language check and discussion. The manuscript benefited strongly from the constructive comments, ideas and discussion by referees Demian Saffer and Mike Tryon. This study was funded by Swiss National Science Foundation (SNF grant 620-066113) and German Science Foundation (to RCOM Bremen). This is RCOM publication 0467.

\section{References}

Baltzer, A., P. Cochonat, and D. J. W. Piper (1994), In situ geotechnical characterisation of sediments on the Nova Scotian slope, eastern Canadian continental margin, Mar. Geol., 120, 291-308.

Biscontin, G., J. M. Pestana, and F. Nadim (2004), Seismic triggering of submarine slides in soft cohesive soil deposits, Mar. Geol., 203, $341-$ 354.

Brodsky, E. E., E. Roeloffs, D. Woodcock, I. Gall, and M. Manga (2003), A mechanism for sustained groundwater pressure changes induced by distant earthquakes, J. Geophys. Res., 108(B8), 2390, doi:10.1029/ 2002JB002321.

Brown, K. M., D. A. Saffer, and B. A. Bekins (2001), Smectite diagenesis, pore-water freshening, and fluid flow at the toe of the Nankai wedge, Earth Planet. Sci. Lett., 194, 97-109.

Brown, K. M., A. Kopf, M. Underwood, J. Steurer, and J. L. Weinberger (2003), Frictional and mineralogic properties of sediments entering the western Nankai subduction zone: Implications for state of stress on the subduction thrust, Earth Planet. Sci. Lett., 214, 589-613.

Brown, K. M., M. D. Tryon, H. R. DeShon, L. M. Dorman, and S. Y. Schwartz (2005), Correlated transient fluid pulsing and seismic tremor in the Costa Rica subduction zone, Earth Planet. Sci. Lett., 238, 189203.

Bryn, P., K. Berg, C. F. Forsberg, A. Solheim, and T. J. Kvalstad (2005), Explaining the Storegga slide, Mar. Pet. Geol., 22, 11-19.

Casagrande, A. (1936), The determination of preconsolidation load and its significance, paper presented at the First International Conference on Soil Mechanics and Foundation Engineering, Cambridge, Mass., 22-26 June.

Cocco, M., and J. R. Rice (2002), Pore pressure and poroelasticity effects in Coulomb stress analysis of earthquake interactions, J. Geophys. Res., 107(B2), 2030, doi:10.1029/2000JB000138.

Davis, E. E., G. C. Horel, R. D. McDonald, H. Villinger, R. H. Bennett, and H. Li (1991), Pore pressures and permeabilities measured in marine sediments with a tethered probe, J. Geophys. Res., 96(B4), 5975-5984.

Davis, E. E., K. Becker, K. Wang, K. Obara, Y. Ito, and M. Kinoshita (2006), A discrete episode of seismic and aseismic deformation of the Nankai trough subduction zone accretionary prism and incoming Philippine Sea plate, Earth Planet. Sci. Lett., 242, 73-84.
Dugan, B., and P. B. Flemings (2000), Overpressure and fluid flow in the New Jersey continental slope: Implications for slope failure and cold seeps, Science, 289, 288-291.

Esrig, M. I., R. C. Kirby, and R. G. Bea (1977), Initial development of a general effective stress method for the prediction of axial capacity for driven piles in clay, paper presented at the 9th Annual Offshore Technology Conference, Houston, Tex., 2-5 May.

Hampton, M. A., H. J. Lee, and J. Locat (1996), Submarine landslides, Rev. Geophysics, 34, 33-59.

Hubbert, M. K., and W. W. Rubey (1959), Role of fluid pressure in the mechanics of overthrust faulting. I: Mechanics of fluid filled porous solids and its applications to overthrust faulting, Geol. Soc. Am. Bull., 70, 115-166.

Ilstad, T., J. G. Marr, A. Elverhoi, and C. B. Harbitz (2004), Laboratory studies of subaqueous debris flow by measurements of pore-fluid pressure and total stress, Mar. Geol., 213, 403-414.

Karakouzian, M., B. B. Avar, N. Hudyma, and J. A. Moss (2003), Field measurements of shear strength of an underconsolidated marine clay, Eng. Geol. Amsterdam, 67, 233-242.

Lee, D. S., and D. Elsworth (2004), Indentation of a free-falling sharp penetrometer into poroelastic seabed, J. Eng. Mech., 130, 170-179.

Locat, J. (2001), Instabilities along ocean margin: A geomorphological and geotechnical perspective, Mar. Pet. Geol., 18, 503-512.

Logan, J. M., and K. A. Rauenzahn (1987), Frictional dependence of gouge mixtures of quartz and montmorillonite on velocity, composition and fabric, Tectonophysics, 44, 87-108.

Lunne, T., P. K. Robertson, and J. J. M. Powell (1997), Cone Penetration Testing in Geotechnical Practice, Taylor and Francis, Philadelphia, Pa.

Lupini, J. F., A. Skinner, and A. E. Vaughan (1981), The drained residual strength of cohesive soils, Géotechnique, 31, 181-213.

Masson, D. G., A. B. Watts, M. J. R. Gee, R. Urgeles, N. C. Mitchell, T. P. Le Bas, and M. Canals (2002), Slope failure on the flanks of the western Canary Islands, Earth Sci. Rev., 57, 1-35.

Moore, J. C., and Shipboard Party ODP Leg 156 (1995), Abnormal fluid pressures and fault-zone dilation in the Barbados accretionary prism: Evidence from logging while drilling, Geology, 23, 605-608.

Moore, J. G., W. R. Normark, and R. T. Holcomb (1994), Giant Hawaiian underwater landslides, Science, 264, 46-47.

Saffer, D. M., E. A. Silver, A. T. Fischer, H. J. Tobin, and K. Moran (2000), Inferred pore pressures at the Costa Rica subduction zone; implications for dewatering processes, Earth Planet. Sci. Lett., 177, 193-207.

Schnellmann, M., F. Anselmetti, D. Giardini, and J. A. McKenzie (2005), Mass movement-induced fold-and-thrust belt structures in unconsolidated sediments in Lake Lucerne (Switzerland), Sedimentology, 52, 271-289.

Schultheiss, P. J. (1990), Pore pressures in marine sediments: An overview of measurement techniques and some geological and engineering applications, Mar. Geophys. Res., 12, 153-168.

Stegmann, S., H. Villinger, and A. Kopf (2006), Design of a modular, marine free-fall cone penetrometer, Sea Technol., 47(2), 27-33.

Strasser, M., S. Stegmann, F. Bussmann, F. S. Anselmetti, B. Rick, and A. Kopf (2007), Quantifying subaqueous slope stability during seismic shaking: Lake Lucerne as model for ocean margins, Mar. Geol., in press.

Sultan, N., et al. (2004), Triggering mechanism of slope instability processes and sediment failures on continental margins: A geotechnical approach, Mar. Geol., 213, 291-321.

Terzaghi, K. (1925), Erbaumechanik auf bodenphysikalischer Grundlage, 399 pp., Franz Deuticke, Leipzig, Germany.

von Huene, R., C. R. Ranero, and P. Watts (2004), Tsunamigenic slope failure along the Middle America Trench in two tectonic settings, Mar. Geol., 203, 303-317.

F. Anselmetti and M. Strasser, Geological Institute, ETH Zürich, Universitätstrasse 16, CH-8092 Zurich, Switzerland.

A. Kopf and S. Stegmann, Research Centre Ocean Margin, University of Bremen, P.O. Box 330440, D-28334 Bremen, Germany. (stegmann@ uni-bremen.de) 